\title{
Máire Dwyer
}

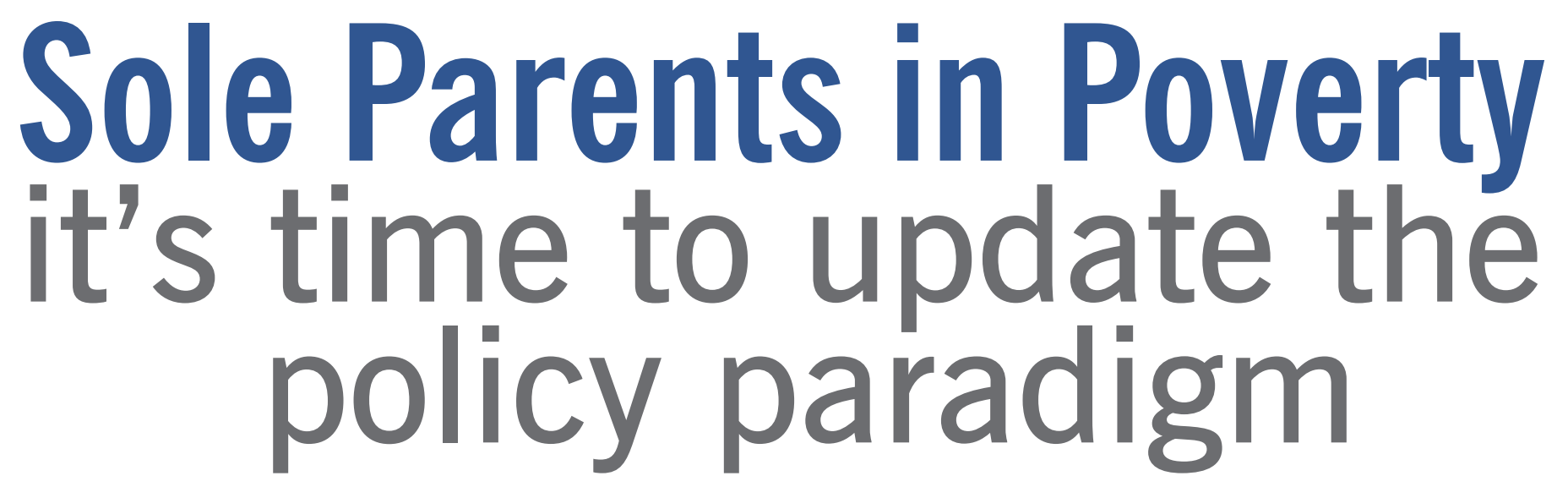

Sometimes you just cry. When your kids are sick you just feel so helpless and you can't give them what they need. Can't take them to the park or anything because there's hardly no food to pack to take. WINZ expect me to run here and there and yet I told them, 'I just finished giving birth. I can't run here and there. Please, I'm already over my limits'. I had my two girls in the car and I had to sleep at Seaside Park with a newborn. Then Child Youth and Family Services might think I'm a bad Mum, with a newborn and nine-year-old and take my kids.

- Work and Income beneficiary quoted in Hodgetts et al. (2014)

In 2013 there were 201,804 sole-parent families in New

Zealand $-84.2 \%$ were female-headed, six in ten with a

youngest child aged under 15 - compared to around 469,290

two-parent families (Statistics New Zealand, 2014a). Around

$90 \%$ of sole-parent families had a level of equivalised

disposable income below the overall median in 2013, compared with 50\% of two-parent families (Perry, 2014).

New Zealand sole-parent poverty rates are particularly high in comparison with those for other groups. In 2013, 18\% of the New Zealand population were poor on a standard poverty measure. ${ }^{1}$ Around one in ten (11\%) two-parent families were poor, but almost six in ten $(56 \%)$ sole-

parent families were poor; $64 \%$ of soleparent families living on their own were poor.

The fact that so many New Zealand sole parents and their families are poor is well known and has been examined by an expert advisory group on solutions

Máire Dwyer is a consultant on gender, welfare, labour market and social policies in New Zealand and the Pacific. She has previously worked in management and policy leadership roles in public and local government sectors in New Zealand and as a development worker in Africa. to child poverty, as well as by many researchers and organisations, including the Child Poverty Action Group, Every Child Counts, the Auckland City Mission's Family 100 project and UNICEF. Despite this, the majority of sole-parent families remain in poverty, and have done so under both Labour- and National-led governments.

Government reports have explored the prevalence of 'vulnerabilities' within sole-parent families and the services that assist individual sole parents to adapt to mainstream expectations and services (e.g. Ministry of Social Development, 2010). This analysis considers where the mainstream itself needs to adapt so that policies work better for sole parents. The article first grounds the analysis in recent insights into the barriers facing New Zealanders who are poor. It then discusses the gender biases in policies 
Figure 1: Distribution of sole parent (SP) and two parent families (2P) by disposable income (Perry, 2014)

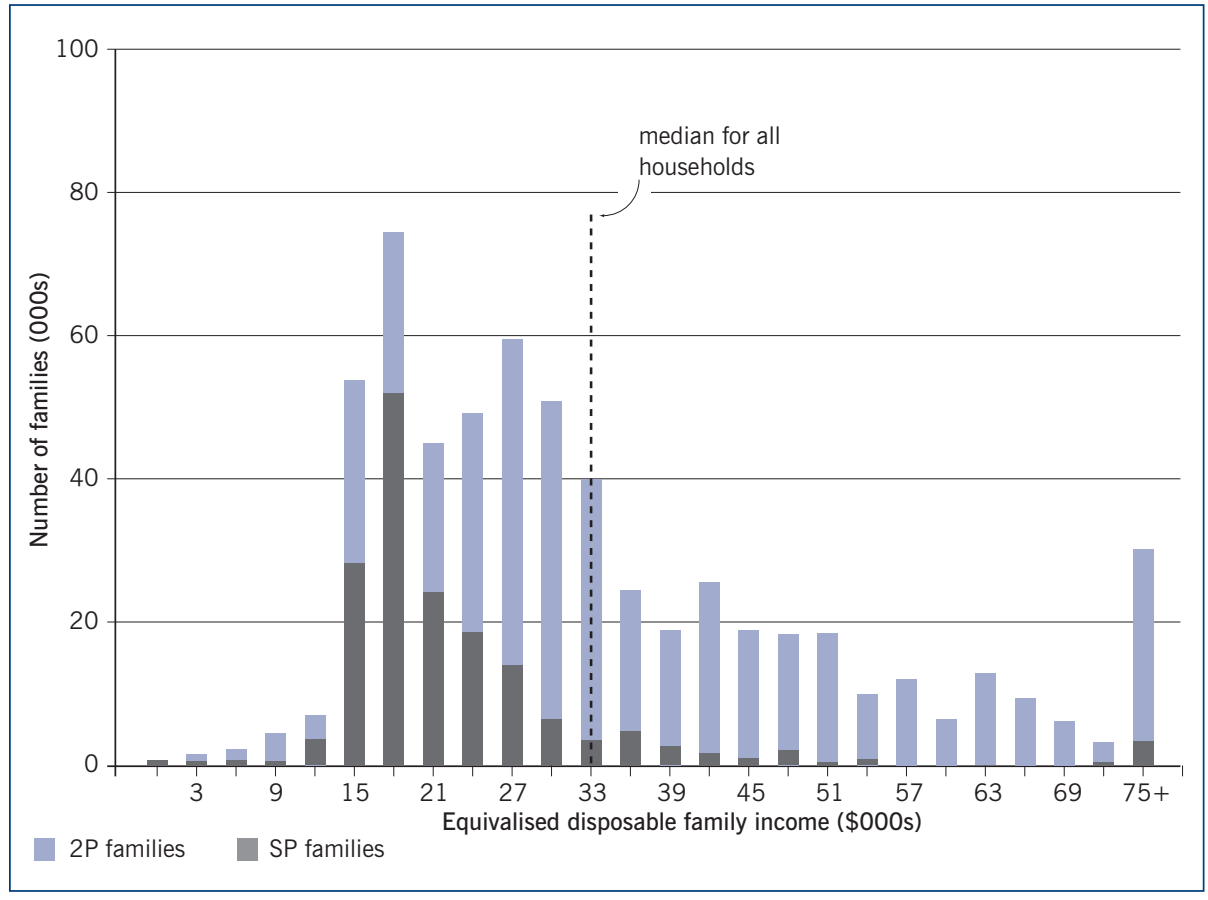

that make it difficult for sole parents to extract themselves from poverty; implicit assumptions in welfare design that need updating; and the contribution of demographics to poverty in Māori and Pasifika families. Finally, it suggests the factors contributing to an outdated, and gender-blind, policy paradigm.

\section{Insights into poverty}

Poverty research invariably finds that overlapping factors influence people's opportunities to get out of poverty. The Auckland City Mission's Family 100 research project draws from a series of multiple interviews with a hundred families who were long-term clients of the mission's food bank, and a representative selection of regular clients. Women were $80 \%$ of project participants (not all were sole parents); $40 \%$ of participants were Māori, 25\% Pasifika, 22\% European, and $13 \%$ Asian or other ethnicity. The participants identified the following factors as contributing to them remaining poor (Auckland City Mission, 2014):

- Debt. Despite budgeting most people had no option but to incur more debt. They turned to expensive sources of credit and this intensified their debt.

- Justice. Lack of money led to unpaid fines. Family members in jail negatively affected children, and visiting cost families. Criminal records made it difficult to gain employment.

- Housing. Many families lived in overcrowded and/or substandard housing far from transport or services. Forced moves and lack of finance constrained options.

- Employment. Participants wanted employment. Poor health and lack of transport were barriers. Low pay rates and variable hours of work contributed to continued poverty.

- Health. Stress, poor nutrition and poor housing and unaffordable services such as dentistry all contributed to poor health.

- Food is the most discretionary item in budgets and therefore what people go without.

- Services. Work and Income offices lack basic facilities such as toilets, and privacy, and seeking help is time-consuming, dehumanising and reinforces a lack of self-esteem and self-worth.

- Education. Children's education is impeded by lack of food for lunches and money for trips and school items. Sole parents lacked pathways to gain higher education.
Poverty rates are high among families that access Whānau Ora, a programme which supports whānau to identify and plan to meet their needs and aspirations. Whānau goals include health, life skills, whakapapa, cultural skills, education and employment. Learning undertaken has included nutrition and healthy lifestyles, budgeting, financial literacy, computer skills, drivers' licensing, and drug and alcohol counselling. Access to information, and building trust, have been identified as preconditions for shifting whānau members from being marginalised to feeling empowered, and to taking steps to access education, support services and employment (Te Puni Kōkiri, 2014).

\section{Systemic barriers to sole parents' agency}

Improving women's agency - that is, 'the ability to make decisions about one's own life and act on them to achieve a desired outcome, free of violence, retribution or fear' (World Bank, 2014) - is key to reducing gender inequality. As exemplified by the 'Girls Can Do Anything' campaign in the 1980s, 'agency' has been essential in reducing gender inequality in New Zealand. However, while having sole charge of a young child or children is a barrier to education, work and other activities, this is not systematically recognised across policy settings.

\section{Education and training policies}

Higher levels of education and skills are associated with higher earnings and less vulnerability to unemployment. In 2010 nearly half of all single parents on welfare benefits had no formal educational qualifications, and a further $44 \%$ had only school qualifications (Ministry of Social Development, 2010). For single people with no children, unemployment following the loss of a job can be a trigger to undertaking more education or training. Independent single people with limited prior tertiary education can generally access a targeted student allowance. For sole parents, the prospects of accessing their chosen tertiary courses are very limited. They do not have enough free time to undertake full-time study or full-time work. The student allowance is for full-time students only. Modern apprenticeships, similarly, are designed 
around full-time work.

If Work and Income case managers agree, sole parent beneficiaries can access the Training Incentive Allowance to cover the full costs of a limited range of pretertiary courses, and up to $\$ 5000$ per year, reassessed every year, for agreed undergraduate courses. Beneficiaries can also be directed to undertake training by Work and Income. Some do take on student loans, but these do not necessarily lead to secure, adequately paid jobs. Many beneficiaries are reluctant to take on a student loan (Auckland City Mission, 2014).

The value of education and training was recognised in the first performance report on the benefit system, undertaken for the Ministry of Social Development in 2013-14 (Ministry of Social Development, 2014a). Developing modular apprenticeships that can be undertaken on a part-time basis and opening up access to student allowances for part-time study in cases where there are caring responsibilities would enable not just sole parents but also other carers to have similar opportunities as other adults to develop their skills.

\section{Employment environment}

There is considerable movement on and off the sole-parent support benefit (Ministry of Social Development, 2014a). While part-time work is manageable for most sole parents, accessing secure employment and hours, as well as having the flexibility needed to care for children, can be problematic. The New Zealand Council of Trade Unions estimates that over 635,000 people, or at least $30 \%$ of the New Zealand workforce, have insecure work (New Zealand Council of Trade Unions, 2013). In 2012, one in ten $(10.4 \%)$ employed New Zealanders were in temporary jobs, with temporary employees disproportionately female, younger, and Māori or Pasifika.

To exit, or stay off, a benefit sole parents need to work a minimum of 20 hours per week, which will entitle them to the minimum family tax credit of $\$ 438$ after tax per week and the in-work tax credit, which provides working families with at least an additional $\$ 60$ net per week. The minimum family and in- work tax credits are not averaged over yearly working hours, so teacher aides, for example, who are contracted from February to December lose not just their work but also the minimum family tax credit over the summer holidays and usually have to sign up again for a benefit (Child Poverty Action Group, undated). Part-work, part-benefit may offer sole parents more security, particularly if they need to be home during school holidays.

Low pay is a further issue of concern, as, even when working, most sole parents have incomes below the median level. In the Decemeber 2012 quarter, median gross hourly earnings for temporary workers were $74 \%$ of those for permanent employees and one in five employees had earnings for the 52 weeks prior to the accident. This means people who are in part-time work, are new to a job or have intermittent employment are unlikely to get an adequate level of compensation. If they access a benefit, this is abated dollar for dollar against the ACC earnings-related compensation, rather than the earningsrelated compensation being treated like any other income.

Paid parental leave is income-related up to a low cap, but requires a mother's continuous employment for at least six months. Given the lack of security in many jobs, this seems an unwarranted constraint and could be replaced by averaging earnings over the same period.

\section{Child Support paid on behalf of a child in a sole-parent family on a benefit is not passed on to the sole parent but used to defray overall costs of the benefit system.}

been in their current job less than a year (Statistics New Zealand, 2013). Around one third of all jobs are part-time, but they are less well-paid on average than full-time jobs. For low-paid sole parents, taking on a full-time job hardly increases their incomes above what they receive from a 20-hour-a-week job (Fletcher, 2011). Current pay structures and job security deserve focus for a number of reasons, including the pursuit of gender equality (Hyman, 2015).

\section{Work-related provisions}

Part-time employment does not bring all the benefits of full-time employment. An accident that prevents a person from working can propel a sole parent onto a benefit. The Accident Compensation Corporation provides $80 \%$ of actual earnings as earning-related compensation. Low-income earners can access the minimum earnings-related compensation payment only if they have been working at least 30 hours a week prior to their accident. After four weeks of payments the $80 \%$ calculation is based on actual

\section{Child care}

Government spending in this area focuses on early childhood education (ECE) rather than on supports for child care that enable caring parents to be in employment. The flagship ECE policy is 20 hours' free early childhood education per week for threeand four-year-olds. Out-of-school care services receive minimal funding, and participation levels are low compared to those in other OECD countries (OECD, 2011).

Further, the 20 hours' free ECE is not a good fit with the minimum family and in-work tax credit mechanisms that enable sole parents to stay off, or move off, benefits. Sole parents need more than 20 hours of ECE to engage in 20 hours of paid work.

The Ministry of Social Development's targeted child care subsidy is available for up to 50 hours care per week for those in work or approved training, but it is not a full payment. The most generous provision is only available to teenage sole parents on a benefit, who can access the guaranteed childcare assistance payment 
of up to $\$ 6$ an hour for up to 50 hours a week when they engage in approved activities.

\section{Financial support}

Sole parents on welfare benefits

Currently, sole parents can access sole parent support with a requirement to look for part-time work when their youngest child is aged five. ${ }^{2}$ Sole parents with a youngest child aged 14 or older can access job search support with full-time work expectations.

\section{Child Support}

Child Support paid on behalf of a child in a sole-parent family on a benefit is not passed on to the sole parent but used to

\section{Constraints on relationships}

Welfare benefits are tightly targeted on the income of the immediate nuclear family. Entitlement to sole parent support ceases when a beneficiary marries or enters into a de facto relationship. ${ }^{3}$ Ministry of Social Development manuals and protocols direct very early interventions in cases where clients have an emerging relationship. Case managers are encouraged to negotiate a time frame of up to six weeks with a client to allow them to decide whether the client will enter into a de facto relationship. They are directed to discuss cases where they are unable to make a decision regarding the client's relationship with their regional solicitor or the Fraud Investigation Unit.

\section{Our history of income support for families stems from a 'wage earner welfare state' established in the 1930s, when 1935 labour legislation decreed that a 'family wage' paid to adult male workers ...}

defray overall costs of the benefit system. It is, however, passed on to the parent in cases where that parent has repartnered, even if the couple receive a benefit. Sole mothers who cannot, or do not, name the father of their child are usually penalised by receiving a lower level of benefit. Failure to pass on all or some of Child Support paid is out of step with international practice, and has been criticised internationally and nationally as unfair and contributing to both child poverty and disaffection on the part of the parents who contribute Child Support.

\section{Parental tax credit}

The government pays a parental tax credit to parents not eligible for paid parental leave, on the birth of a child. To access the parental tax credit, families need to be off benefit. This is a relatively easy test for a two-parent family, but difficult for almost all sole parents.
Having to determine whether a relationship exists within such a short time frame contrasts markedly with the three years of cohabitation required before the equal sharing rules of the property relations legislation apply. It is out of step with social norms whereby it is now usual for de facto cohabitation to be the first form of relationship, and for cohabitation to occur before marriage (New Zealand Families Commission, 2013, p.56). These procedures constrain normal adult freedoms and the shortterm relationships which may or may not become long-term commitments. The threat of loss of benefit as a consequence of engaging in any sort of relationship lessens sole parents' opportunities to manage their own lives and establish themselves in a supportive relationship.

\section{Accommodation supplement}

The design of the tightly targeted accommodation supplement provides a lower maximum amount of support for a sole parent with one child than it does to a couple with one child, even though both households require the same number of bedrooms.

\section{Working for Families}

The Working for Families tax credits, implemented between 2004 and 2007, increased the amount families received from the family tax credit, accommodation supplement and childcare assistance payment. It increased the level of the minimum family tax credit and removed the child component of main benefits. As an incentive for families to be in paid work, the in-work tax credit replaced a child tax credit

The hours of work requirements for the in-work and minimum family tax credits favour two-parent families. The requirements for a couple are 30 hours per week between them, whereas a sole parent must work 20 hours a week. So long as one parent in a two-parent family meets the 30 hour requirement, the family can access the in-work tax credit until their youngest child is 18. These time-based requirements fail to take into account the similar levels of unpaid care work that sole parents and couple parents must undertake, and how that impacts on the time parents have available for work.

The need to replace the breadwinner paradigm

Our history of income support for families stems from a 'wage earner welfare state' established in the 1930s, when 1935 labour legislation decreed that a 'family wage' paid to adult male workers needed to be sufficient to maintain a wife and three children (Castles and Shirley, 1996). In contrast, European and Scandinavian welfare developed around a social insurance model. Our welfare arrangements today depend on nuclear families supporting family members through their own income, with government providing residual, targeted support. ${ }^{4}$ This arrangement was never one which would enable women to reach their potential, but today it is even less satisfactory.

Growing numbers of families do not fit the primary breadwinner model. 
Substantial changes since the 1970s include: increased female labour force participation; an increased share of families headed by a sole parent; a growing proportion of children who spend some time in a sole-parent family; marriage being no longer as prevalent, nor as enduring; the growth of insecure and irregular employment; widening wage differentials; and the increased vulnerability of low-skilled workers to unemployment.

Working for Families, ECE policies and the employment environment reinforce women's role as 'secondary earners' who are semi or fully-dependent on men through: the high effective marginal tax rates facing second earners in low- and middle-income families; the difficulties of affording and acquiring enough child care for both parents to work full-time; and the generally poor quality of jobs that are available on a part-time basis.

Moreover, the in-work tax credit has not achieved its goal of increasing parents' involvement in work. An evaluation by the Ministry of Social Development and Inland Revenue found that around 8,100 more sole parents engaged in work as a result of the Working for Families changes, although gains were lost following the economic downturn in 2009. It also found that 9,300 fewer second earners in twoparent families were in paid employment. This was somewhat disingenuously described as giving 'couple parents greater choice about working and caring for their children by making it easier to manage on less income from the labour market' (Ministry of Social Development and Inland Revenue, 2010). Never mind about choice for sole parents, or couples where low pay meant both had to work, or where one or both were unable to work due to illness or invalidity. More genderaware analysis would have pointed out that poor work incentives for second earners not only compromises the goals of the policy, but means that taxpayers are supporting some families who could engage in more paid work than they do currently. Anyone who is out of work for a long time loses workforce skills, reducing their future employability and potential earnings. They also increase their vulnerability to poverty and

reliance on welfare if their partner loses their job or their relationship breaks down. Over a quarter of sole parents become beneficiaries as a consequence of relationship breakdown.

In the case of unemployment or sickness, benefit entitlements determined on the basis of joint family income do not meet the social insurance needs of the majority of couples, who have two earners, pay tax as individuals and have commitments based on two incomes. The current framework fails to adequately recognise caring responsibilities, and makes it difficult for adults with limited earning potential (such as sole parents and invalids) to form a new relationship without becoming dependent on another adult.

\section{... policy advisers have yet to come to terms with the diversity of family forms and the different demographics of populations.}

This issue needs a fuller discussion than is possible here. However, women's participation levels in the labour force are now almost equal to men's, most mothers of dependent children are now in paid work, and, on average, young women are achieving better education outcomes than young men. It is timely to consider expanding individual entitlements to social insurance beyond ACC to cover sickness and unemployment, and to ensure more explicit recognition of responsibilities for care. This is key to reducing women's greater vulnerability to reliance on benefits or partners and achieving gender equality.

The need to take account of the youthfulness of the Mãori and Pasifika populations

Māori and Pasifika populations have around twice as many children to support per working-age adult as does the Pākehā population. Qualifications, and therefore wages and employment prospects, are also lower on average, and they have poorer outcomes in a number of areas, including health, violence and incarceration. Due to lower life expectancy and their youthful population, there are fewer retired people available to support children and grandchildren. Not surprisingly, their labour force participation $(66.7 \%$ for Māori, 63.1\% for Pasifika), but more particularly their employment rates (58.5\% and 55.7\% respectively), are lower than is the case for Pākehā (69.9\% and 67\%) (Statistics New Zealand, 2014b).

Demographics affect the level of welfare take-up by different populations. To get ahead these young populations need more than strategies to assist people into work. In the 1950s and 1960s the Pākehā population had a similar youthful demographic. Social policy then focused on the needs of young families, and included home help, housing programmes to get young families into their own homes, and the creation of suitable facilities for children.

\section{Concluding comments}

Most sole parents in New Zealand struggle to make ends meet. For too many there is no visible pathway into decent work and off the benefit. Why is policy not delivering better outcomes for sole parents? I suggest there are four contributing factors.

First, the Better Public Services goal of reducing long-term welfare dependency is a poorly specified goal which, perversely, may be leading to more gatekeeping around access to benefits and premature exiting of beneficiaries. Important outcomes, such as improvements in sole parents' wages and total incomes, are not monitored at all by the Ministry of Social Development (Ministry of Social Development, 2014b).

Second, welfare policy remains dominated by orthodox economic analysis which has never taken unpaid care and household work into account. Moreover, the archetype of an unfettered 
'economic man' could not be further from the reality of a woman in sole charge of young children. In its focus on individual incentives, current welfare policy misses the bigger picture of constrained choices and the distribution of responsibilities for raising the next generation.

Third, policy is still largely siloed and decided within a certain department's budget. The Ministry of Social Development's investment approach has identified the long-term costs within ministry benefits, but does not include the costs of impoverished families elsewhere in the system, and the long-term costs of Working for Families. It is focused on investments within the welfare system, not broader system changes, such as child care policies and lower income taxes, that could have positive impacts on the trajectories of sole parents and others.
Finally, policy advisers have yet to come to terms with the diversity of family forms and the different demographics of populations. Many policy initiatives consider only the aggregate impacts of change, rather than the needs of, or impacts on, particular groups, including women and men. This suggests a lack of diversity of thought in policy leadership, and limited capability around population and gender issues. More gender analysis would bring to the fore the differential impacts of policy on women and men, and other population subgroups, and recognise that systems and policies are evolving from gender-inequitable starting points. It would enable the identification of policy options which will reduce gender-based inequalities and support social norms that reinforce gender equality.

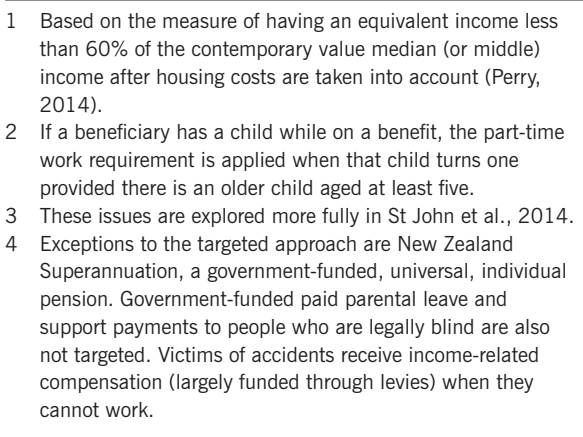

\section{Acknowledgements}

I would like to thank Michael Fletcher, Rachel Simon-Kumar, Tony McGurk and Susan St John for comments on an earlier draft of this article.

\section{References}

Auckland City Mission (2014) Speaking for Ourselves: the truth about what keeps people in poverty from those who live it, Family 100 research project

Castles, F. and I. Shirley (1996) 'Labour and social policy: gravediggers or refurbishers of the welfare state', in F. Castles, R. Gerritsen and J. Vowles (eds), The Great Experiment: labour parties and public policy transformation, Auckland: Auckland University Press

Child Poverty Action Group (2014) Our Children, Our Choice: priorities for policy series, Auckland: Child Poverty Action Group

Child Poverty Action Group (undated) 'The In Work Tax Credit in Practice: a reality check for the IRD'

Fletcher, M. (2011) 'Some policy issues for reforms of assistance to sole parents', Policy Quarterly, 7 (2), pp.38-45

Hodgetts, D., K. Chamberlain, S. Groot and Y. Tankel (2014) 'Urban poverty, structural violence and welfare provision for 100 families in Auckland', Urban Studies, 51 (10)

Hyman, P. (2015) 'Is active intervention still needed to improve the position of women in the New Zealand labour market? If so, what can be done?', Policy Quarterly, 11 (1) pp.3-10

Ministry of Social Development (2010) Sole Parenting in New Zealand: an update on key trends and what helps reduce disadvantage, Centre for Social Research and Evaluation, Inland Revenue

Ministry of Social Development (2014a) Work and Income 2013 Benefit System Performance Report for the year ended 30 June 2013, Wellington: Ministry of Social Development

Ministry of Social Development (2014b) Annual report 2013-14

Ministry of Social Development and Inland Revenue (2010) Changing Families' Financial Support and Incentives for Working: the summary report of the evaluation of the Working for Families package, Wellington: Ministry of Social Development and Inland Revenue
New Zealand Council of Trade Unions (2013) Under Pressure: a detailed report into insecure work in New Zealand, http://union.org.nz/ underpressure

New Zealand Families Commission (2013) Families and Whānau Status Report: towards measuring the wellbeing of family and whānau, Wellignton: New Zealand Families Commisson, http://www. familiescommission.org.nz/publications/research-reports/families-andwh\%C4\%81 nau-status-report-2013

OECD (2011) Doing Better for Families, Paris: OECD

Perry, B. (2014) Household Incomes in New Zealand: trends in indicators of inequality and hardship 1982 to 2013, Wellington: Ministry of Social Development

St John, S., C. MacLennan, H. Anderson and R. Fountain (2014) The Complexities of 'Relationship' in the Welfare System and the Consequences for Children, Auckland: Child Poverty Action Group, http://www.cpag.org.nz/assets/141204CPAG\%20Welfare\%20 System\%20final.pdf

Statistics New Zealand (2013) Survey of Working Life: December 2012 quarter, Wellington: Statistics New Zealand

Statistics New Zealand (2014a) 2013 Census QuickStats about families and households, Wellington: Statistics New Zealand

Statistics New Zealand (2014b) Household Labour Force Survey: September 2014 quarter, Table 5, Wellington: Statistics New Zealand Te Puni Kōkiri (2014) Whānau Ora Results - January-March 2014

World Bank (2014) Voice and Agency: empowering women and girls for shared prosperity, Washington, DC: World Bank Group 